\title{
The Power of Geometric Relationships in Mudéjar Timber Roof Frames
}

\author{
Angel Candelas-Gutierrez ${ }^{1}$ (D)
}

Published online: 29 April 2017

(C) Kim Williams Books, Turin 2017

\begin{abstract}
Research into the modulation, proportions and units of measurement inherent to historical buildings confirms the existence of modules based on standard units of measurement, anthropometric measurements and various proportional relationships. This article examines a system based on the use of timber width as a unit of measurement and a base construction module. This system was used to build complex timber roof frames across a broad geographic and temporal scope, stretching from the Iberian Peninsula to large expanses of North Africa and from the Late Middle Ages to the beginning of the Renaissance. The principal aim of this study is to demonstrate the power of that system which, as shown in this article, allows us to recreate today a large portion of a roof frame geometry based on a tiny fragment of the structure to which it belongs, with relevance both to design and to historic preservation.
\end{abstract}

\section{Introduction}

There is ample bibliography, as we shall see, on the modulation, proportions and sizing of historical buildings stretching from Antiquity to the present day, and in every culture. In very general terms, these interpretations of the geometry of historical buildings may be classified into two broad groups: (1) studies that aim to define the proportions inherent to the floor plan, section or elevations of a building; (2) studies that examine the different local—often anthropometric-systems of measurement and how they were used in buildings. In many of these studies the analysis suggests that the two types were interrelated. However, it is much rarer to

Angel Candelas-Gutierrez

alcg@us.es

1 Escuela Técnica Superior de Arquitectura, Departamento de Construcciones Arquitectónicas I, Universidad de Sevilla (Spain), Avda. Reina Mercedes, 41013 Seville, Spain 
find studies where the system of measurement is based on the specific dimensions of a basic construction element which, coupled with a set of rules, is then used to build an entire and very complex structure. It was precisely a system of this type that Mudéjar carpenters used to build elaborate roof structures.

Ancient systems of measurement and their use in architecture have been studied since earlier periods to the present day (Klein 1974; Fernie 1978; Kula 1980; Michell 1981). In particular, Francisco Roldán-Medina has shown, for example, that an anthropometric system of measurement was used in the Great Mosque of Córdoba (Roldán 2012; Roldán-Medina 2015).

There are also various studies on the measurement systems used in specific regions. For example, in his study of medieval town halls in Flanders, Han Vandevyvere (2001) examines several buildings and argues that "the emblematic city hall was always set out in local measures", pointing out the continued use of the local unit of measurement, namely the particular "rod" of each city. Meanwhile, Aineias Oikonomou found in his study on 15th and 16th-century post-Byzantine churches in north-western Greece (2012) that the design was based on the Byzantine foot. In Spain, Felix Hernández Jiménez (1961) made an important contribution to the debate in his study of the Arabic cubit as a unit of measurement in Islamic buildings.

With regard to studies on modulation and systems of proportions, the contributions of Matila Ghyka (1931), Rudolf Wittkover (1960) and José Antonio Ruiz de la Rosa (1987) have shed significant light. Those studies have continued, as we can see for instance in (Corcuff 2012).

The aim of this present article is to describe and demonstrate the potentiality of the procedures used in the construction of Spanish Mudéjar roof structures. Using the same rules that medieval carpenters followed, we will see how a tiny fragment of a frame can reveal the entire geometry of the structure to which it belongs. To do this, we will briefly explain some of the geometric procedures followed and then transcribe them into mathematical terms.

This article examines the particular case of the sizing procedures that were used in Spanish medieval timber roof frames, also known as Mudéjar timberwork, as well as in parts of the modern-day Maghreb. We shall see how in these buildings the unit of measurement is an intrinsic dimension of each work in particular-the timber width - rather than a fraction or addition of the prevailing unit of measurement or a specific proportion imposed extrinsically. The use of this unit of measurement combined with the knowledge of how to divide a circumference into a specific number of parts gave rise to a set of sizing rules with an extraordinary potentiality for creating complex structures. Following a strict rule-based system, medieval carpenters had the ability - and intelligence - to create original and highly complex formations in roof frames and other architectural elements. Faithful adherence to these rules today allows us to determine the entire geometry of a structure based on a tiny fragment that formed part of it.

Our insight into these procedures has come down to us through later texts, written in the seventeenth century, but nevertheless containing medieval building knowledge that was clearly passed on orally within the carpentry guild. Here I shall limit myself to briefly explaining the rules I have used to demonstrate the potentiality of 
these geometric relationships, although I also include conclusive evidence that they were indeed used in a variety of major historical buildings.

Comparable references in the Western world to the adoption of the size of a construction element as the base unit of measurement have not been found. However, a similar system, again based on timber width, was used in Chinese buildings until at least the twelfth century, as indicated in the Yingzao Fashi and shown by Demiéville (1925) and Li (2011).

In this article the term "Mudéjar" is used to refer to an architectural style rather than to indicate authorship. As pointed out in (Shtrum et al. 2011), "Mudéjar refers to the Moors or Muslims who remained in the Christian territory after the Reconquest of Spain but who did not convert to Christianity". However, the research conducted by Enrique Nuere Matauco (2000) attributes the origin of these constructions to the artisans of the Kingdom of Castile, although they introduced designs rooted in the Islamic tradition. A more appropriate term might be "carpinteria de lo blanco", or whiteness carpentry, since this was the name of the medieval guild to which these artisans belonged. Nevertheless, as Joaquín García Nistal (2011) rightly points out, it is difficult to pin down the exact meaning of the term. Indeed, there is still no conclusive evidence of the cultural (Islamic or Christian) or geographic (Iberian or African-Asian) origins of this system, although Federico Wulff Barreiro (2010) has provided an interesting and well-documented insight into how and where it emerged. In any case, this important issue merits its own specific investigation, and will not be discussed here.

The geographic context of the buildings discussed in this article encompasses practically the whole of the Iberian Peninsula, including both the Christian kingdoms and Islamic courts, but it also extends to North Africa and left its mark in countries of South America belonging to the old Kingdom of Castile.

Examples of this, to name geographically distant elements, are the roof of the 12th-century mosque in Marrakech (Fig. 1) and the roof of the Chapel of Santiago in the 13th-century Monastery of Las Huelgas, Burgos (Fig. 2) at the other end of the geographical spectrum. Another interesting case, due to its particular complexity and use of the same system, is the construction of highly complex domes like the one over the Ambassadors' Hall in the Alcázar Palace in Seville (c. 1427) (Fig. 3).

\section{Historical Background of Roof Carpentry Techniques}

From the Middle Ages to the Renaissance the most common typology for building the roofs of civic and religious buildings in a wide geographic area was the $\mathrm{s}$ o-called "rafter system". The configuration of these structures is relatively simple, consisting of pairs of rafters meeting at the ridge beam and connected at an intermediate height to a horizontal beam known as a collar beam. These sets of rafters and collar beams are placed very close together and distributed sequentially, without any purlins. Stability is procured by the regular distribution of tie beams. In 


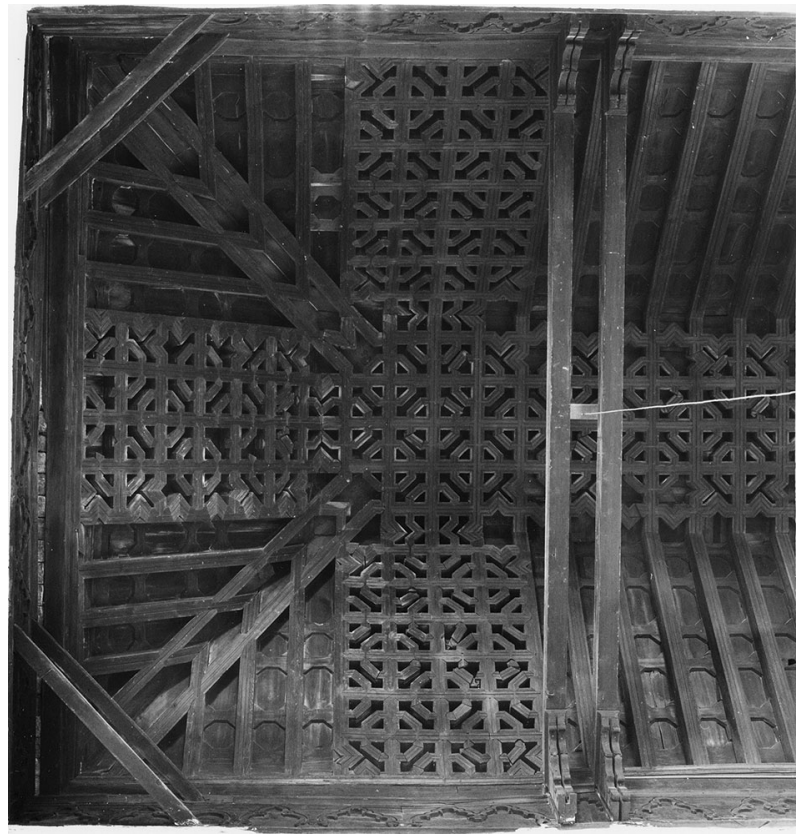

Fig. 1 Roof frame of the mosque in Marrakech (Morocco) (12th century). Photo courtesy of Christian. Ewert

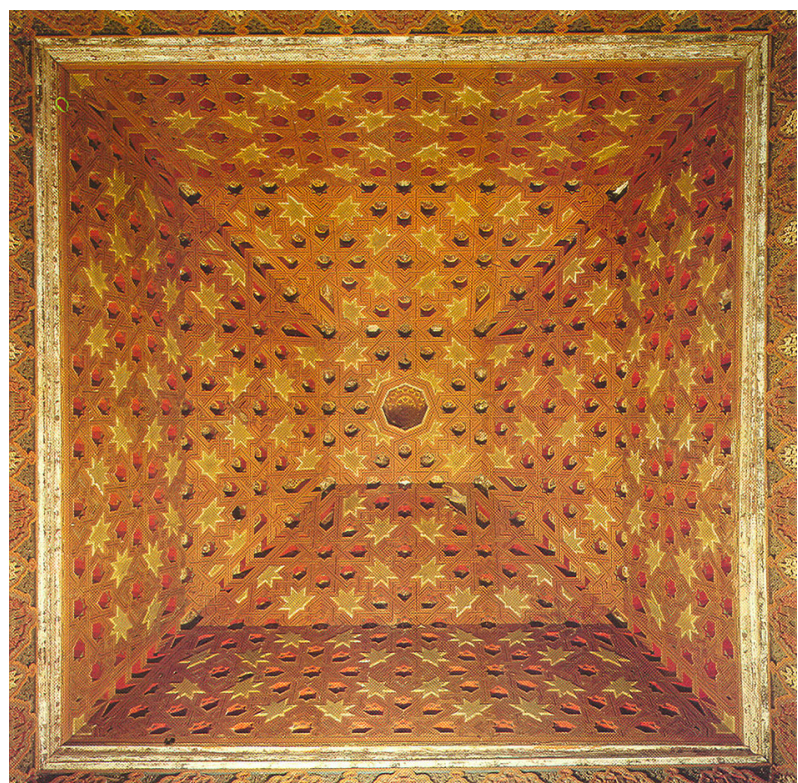

Fig. 2 Roof frame of the Chapel of Santiago, Las Huelgas, Burgos (Spain) (13th century). Photo courtesy of Enrique Nuere 


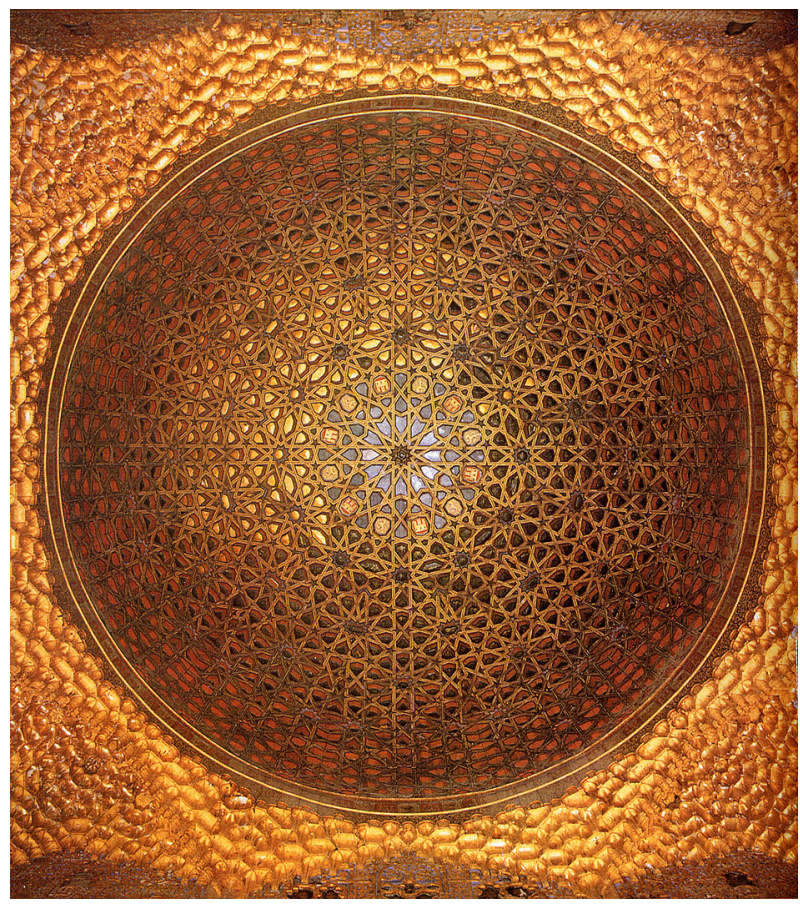

Fig. 3 Roof frame of the Ambassadors' Hall, Alcázar Palace, Seville (Spain) (15th century). Photo by the author

Spanish buildings this system is known as par y nudillo, which roughly translates into English as "rafter and collar beam". 1

This was the customary system used in practically the whole of Europe at the time, with the exception of Italy, where in general the truss and purlin systems inherited from the classical building tradition remained in use. Two studies on timber frames confirm this to be the case in two European countries: France (Deneux 1927) and England (Hewett 1980). With the advent of the Renaissance and the dissemination of the treatises of Palladio and in particular Serlio, the use of truss and purlin systems, possibly more efficient from the structural point of view, spread to the rest of Europe and the rafter and collar beam system was gradually abandoned, as indicated in (Candelas-Gutiérrez 2011).

There is no known medieval text describing the procedure that carpenters followed to build these frames. This absence of documentation is understandable, since carpenters throughout Europe were grouped in guilds and, in the tradition of these organisations, were obligated to retain the secrets of their trade. Coupled with the high illiteracy rate, this would have prevented them from leaving a written testimony of the skills they possessed.

In Spain, however, albeit at a much later date, there are three texts which describe the building methods used by medieval or Mudéjar carpenters and which shed

\footnotetext{
1 (Nuere Matauco and 2000) offers a relevant glossary of the terms used for these constructions.
} 
enormous light on the geometric procedures used. The texts in question are by López De Arenas $(1619,1633)$ and Rodrigo Alvarez (1670), which deal with Spanish timber frames, and a text by Fray Andrés de San Miguel (1652), a Carmelite monk who worked and wrote in Mexico and various countries in Central America. In the case of France, Mathurin Jousse and (1627) wrote a seminal text on French timberwork, which is applicable to a certain extent to Central European timberwork. However, this text deals not so much with the medieval tradition as with the building methods of the seventeenth century, although basically these still included the rafter system.

An important theme common to all these texts is the design process and its execution, which began with the preliminary idea and culminated in the materialisation of the work. Two important aspects are the absence of preliminary plans to define the geometry of the structure to be built, and the determination of the position of the cuts to assemble the pieces of timber. Using a sketch not drawn to scale, which in the case of Spanish timberwork represented the geometry of the panels and the configuration of the interlace design (the muestra) and in the French case was a sketch of the plan (the dessein), the carpenters could go straight from the preliminary idea to the execution.

Interesting to note, in Mudéjar carpentry, we find two different procedures for integrating an interlace pattern into the roof structure, known as ataujerada and apeinazada. ${ }^{2}$ The ataujerada variety of frame almost certainly originated in the Nasrid kingdom of Granada and it consists in overlaying interlace patterns on panels which are then incorporated into the load bearing structure of the roof. The interlace patterns themselves do not bear any of the load. Examples of this type of frame are the famous ceiling of the Comares Hall at the Alhambra (Granada) and the fascinating ceiling on display at the Metropolitan Museum of Art in New York (http://www.metmuseum.org/art/collection/search/451373), which is beautifully described in (Shtrum et al. 2011). These frames lend themselves to extremely complex and diverse interlace patterns since the design is not dependent on the structural configuration. In the other type of frame, the apeinazada, the interlace pattern is integrated into the actual structural elements, forming an indissoluble whole. This article and the illustrations included refer to this latter type, the most predominant in Mudéjar carpentry. An example in the United States is the frame on display at the De Young Museum in San Francisco (https://art.famsf.org/ anonymous/ceiling-palacio-de-altamira-4616).

In Mudéjar frames of the apeinazada variety, the dimensions of the elements were determined by the skilful use of geometric procedures rather than the adoption of a standard unit of measurement, which was used only very rarely. Thus, the width of the timber pieces was a specific submultiple of the width of the room and was used as the unit of measurement to calculate the bay between elements and the depth of the timbers, etc. This unit was used in conjunction with certain set squares which, without the aid of any plans whatsoever, enabled the carpenters to determine where to cut each timber for subsequent assembly in the building and also for the configuration of the interlace designs inserted in the structure.

\footnotetext{
${ }^{2}$ These terms cannot even be translated into modern Spanish. At most, the word "apeinazada" bears some relation to the existence of "peinazos", or noggings, in the interlace pattern.
} 
In the French case, the form was controlled geometrically using a set of auxiliary rules known as "false ties" and "false props", whose dimensions reflected the building width and height, respectively. Divisions made in these rules determined the position of most of the components in the truss, as explained in Jousse (1627).

This modus operandi fits in with the so-called Geometria fabrorum, a set of rules or instructions that allowed master builders to create a wide variety of formsleaving aside any theoretical reflections-using simple geometric concepts. As Ruiz de la Rosa indicates:

In the Middle Ages theoretical knowledge and the knowledge associated with trades parted ways to some extent, with the latter leaning more heavily on certain rudiments of Euclidean geometry and well-established empirical procedures: in short very simple laws which, step by step, allowed them to create and coordinate forms as complex, for different reasons, as a Gothic church or Muslim timberwork (Ruiz de la Rosa 1987: 208).

A unique aspect of these buildings is that the interlace pattern does not only serve an ornamental purpose. The structural elements are integrated into seemingly decorative elements forming interlacing stars, with the result that most of the interlace pattern simultaneously bears the roof load. This is clearly visible in the front and rear sides of a frame fragment on display in the Archaeological Museum in Seville (Figs. 4, 5).

\section{Summary of the geometric rules followed}

The manuscripts of López De Arenas (1619, 1633) and San Miguel (1652) remained undecipherable for a very long time, and their interpretation is primarily owing to the research conducted by Enrique Nuere Matauco (1985, 2000). The treatise by

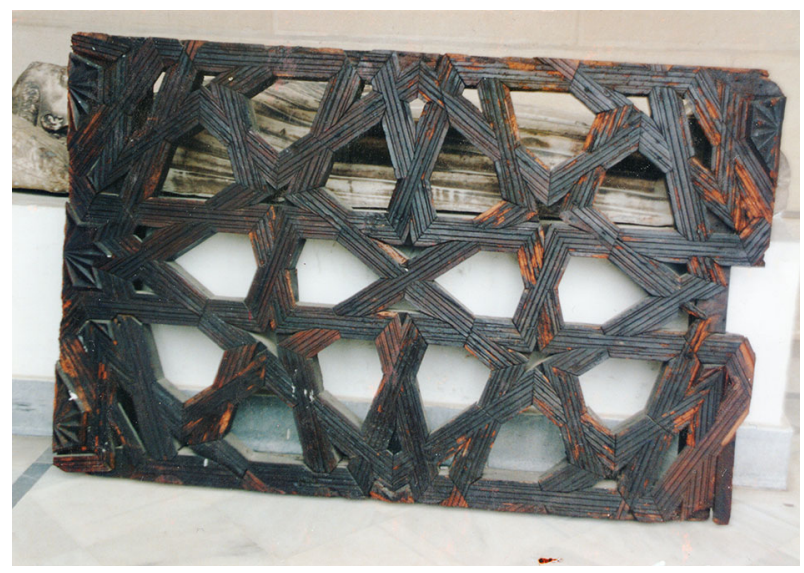

Fig. 4 Fragment of a Mudéjar roof structure at the Archaeological Museum, Seville (Spain) (16th century). Front side. Photo by the author 


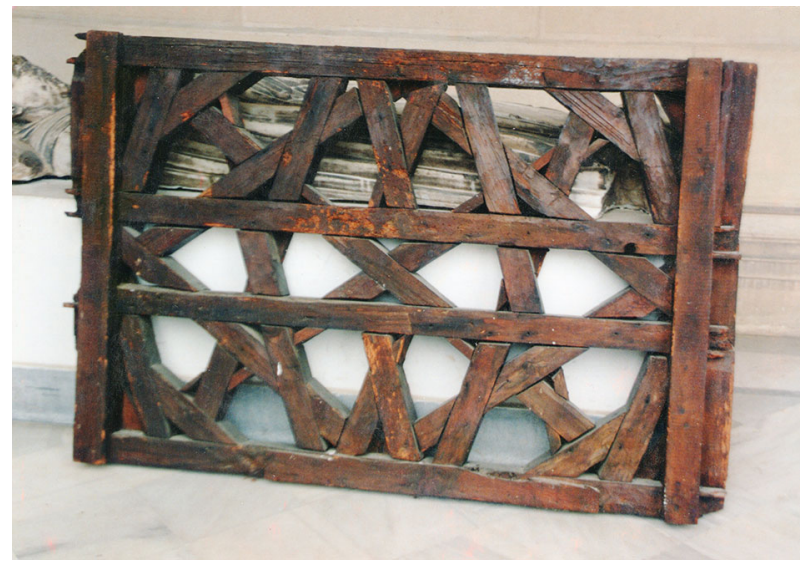

Fig. 5 Fragment of a Mudéjar roof structure at the Archaeological Museum, Seville (Spain), 16th century. Rear side. Photo by the author

Álvarez (1670) remains largely unknown and his manuscript has never been published. These texts all include procedures that lead to the construction of a wide variety of frames and range from the construction of set squares and the definition of element sections to the construction of complex forms like timber domes and vaults; this latter case was studied in (Candelas-Gutiérrez 2000). Before focusing on the principal aim of this present article-to demonstrate their potential for recreating the original structure based on a tiny fragment-we must first briefly describe the main rules followed.

\section{Set Squares}

Among the skills that medieval carpenters possessed was the ability to construct different set squares whose angles they used not only to build structural elements but interlace patterns as well. They knew how to divide a circumference into a specific number of parts, and were even familiar with the procedure for a highly abstract operation such as constructing the set square of " 4 and a half" (division of a semi-circumference into four and a half parts), which is necessary to build a ninepointed star. An extremely illuminating interpretation of the procedures that carpenters followed to divide the circumference in this manner can be found in (Nuere Matauco 2000). Figure 6 illustrates the different set squares according to Álvarez (1670).

It is important to note that the procedures followed to divide a circumference into $n$ parts gave rise in certain cases to only approximate results regarding the original aim, although in all probability this approximation was subsequently corrected. As an example, Fig. 7 shows the procedure for dividing a circumference into five parts. As shown, the angle of division obtained is $53.794^{\circ}$ instead of the $54^{\circ}$ that would correspond to a regular polygon.

As illustrated in Fig. 7, the procedure consists in drawing a circumference with a diameter $\mathrm{BC}$ and from its intermediate point $\mathrm{A}$, always using the same radius 


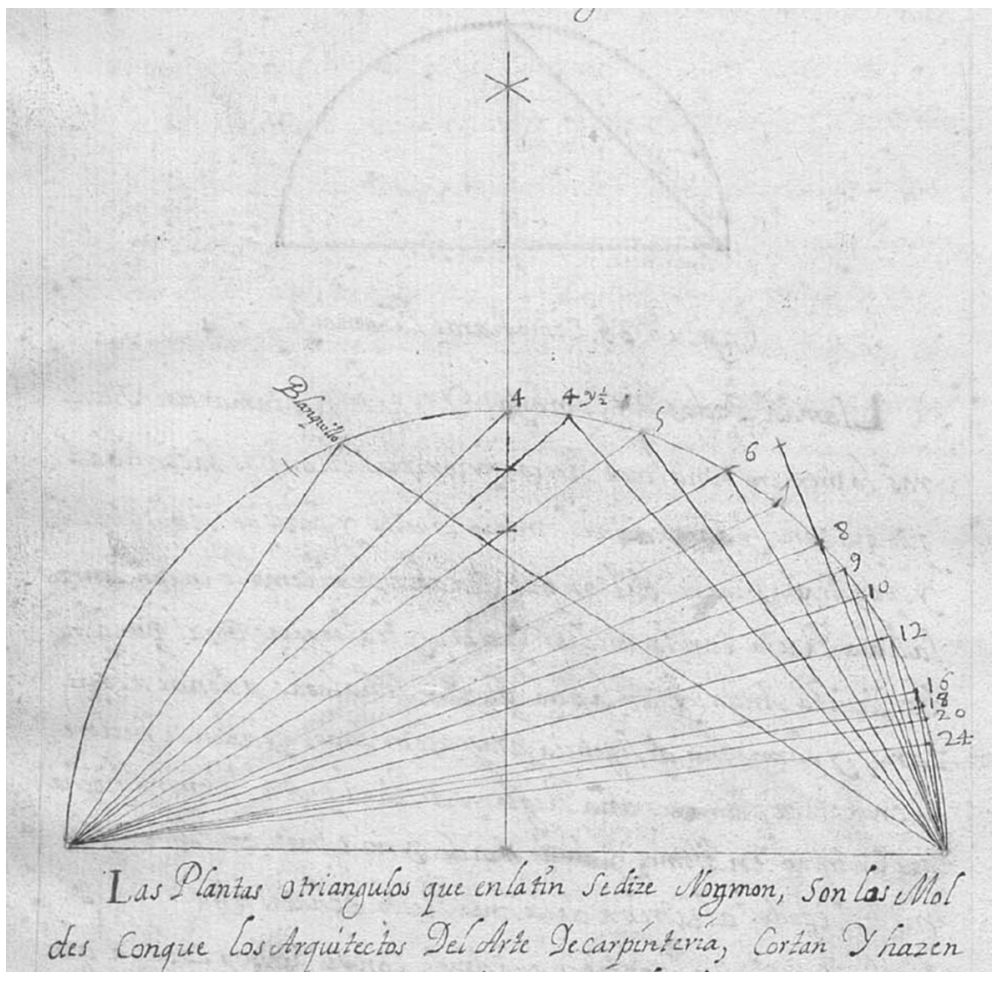

Fig. 6 Set squares. Image: Álvarez (c.1670: 33)

$\mathrm{AB}=\mathrm{AC}$, then drawing circles from $\mathrm{B}$ and $\mathrm{C}$ that intersect the initial circumference at $\mathrm{D}$ and $\mathrm{E}$. From these points are drawn new circumferences intersecting at point F. From F, a new circumference that intersects line AF at point G. Joining CG and drawing a line up to the initial circle produces point $\mathrm{H}$. The triangle $\mathrm{BCH}$ constitutes the "set square of 5".

In a recent article, Lynn Bodner (2012) ponders and answers the following question: "How did artisans and master builders centuries ago create elaborate Islamic star polygon designs?" The manuscripts referenced there clearly describe the procedures used by Mudéjar carpenters. Using only the set square and the timber width as the unit of measurement, they could not only draw complex interlace patterns but also insert them into the load-bearing structure of the roof. Carpenters discovered that interlacing stars and polygons were composed of a very small number of repeated elements, which today we would describe as a polar rotation around the centre of the star. The description of these procedures is for another article, although mention may be made of the genesis of nine and 12-pointed stars in Spanish timberwork because it contrasts with the procedures Bodner describes for the same formation.

To draw an interlacing nine-pointed star polygon, a carpenter only needed to know how to construct five pieces since the entire formation is created through a 


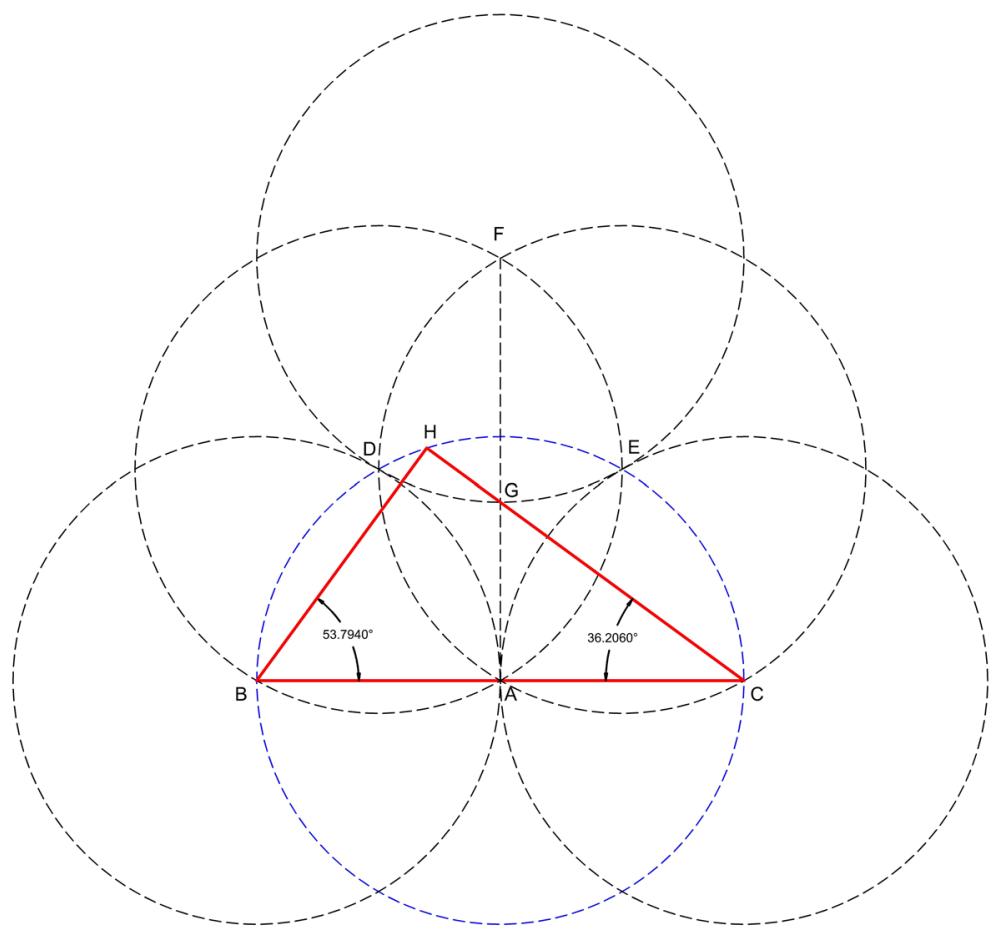

Fig. 7 Procedure for the construction of the "set square of 5". Inexact division of a semi-circumference into 5 parts. Drawing by the author

polar rotation of these pieces with the base at the centre of the star. Most astonishing of all, perhaps, is that to draw an interlacing twelve-pointed star polygon design connected to the former, he only needed to know how to draw an additional four pieces. Figure 8 shows this drawing and the basic pieces of the system; (Nuere Matauco 2000) contains a detailed description of how these basic pieces were generated.

\section{Timber Width as a Unit of Measurement: How this Width was Defined}

Until at least the sixteenth century it was common practice to commission the execution of a roof from carpenters directly, without any involvement of the masons or builders of the supporting walls and arches. The carpenter would therefore find a specific geometry already in place, usually a square or rectangular base, on which to rest the roof structure. More often than not, this structure would need to include an interlace pattern.

An interlace pattern dictates a specific rhythm in the sequencing of the elements in a structure. The most common pattern was to place the timbers a calle y cuerda, as it is described in the treatises. This layout consisted in spacing the timbers, rafters and collar beams at regular intervals based on the actual width of the timber used; the bay between rafters was usually twice their width. This is described for example 


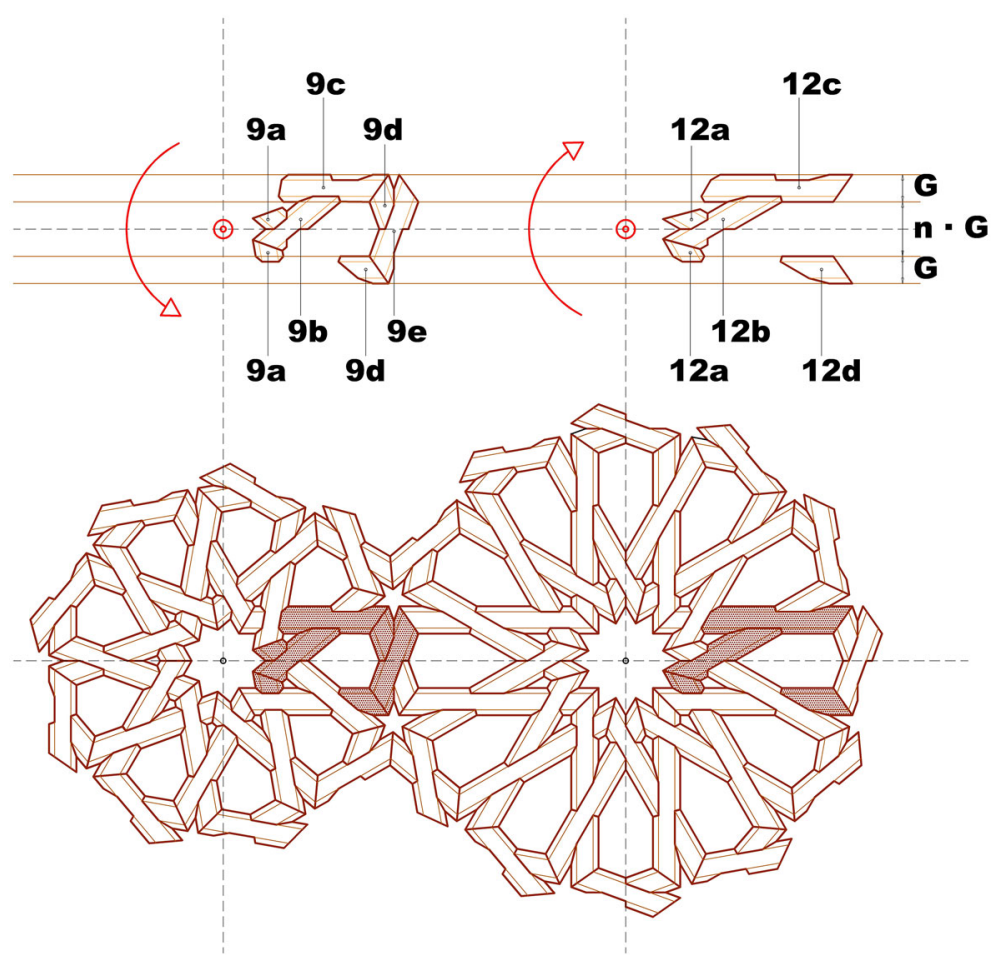

Fig. 8 Construction of nine and twelve-stars-pointed polygon designs based on the knowledge of only five and four basic pieces, respectively. Drawing by the author

in Álvarez's treatise: "The building is divided from one corner or angle of the wall plate to the opposite angle in three equal parts, and one of these partitions is what the collar beam must measure" (c. 1670: 40v). ${ }^{3}$

Figures 9 and 10 confirm the use of this rule in works built across a widely varying geographic, cultural and temporal scope. Figure 9 shows adherence to the rule in a sixteenth-century church in Ayamonte, Spain, while Fig. 10 illustrates the modulation adopted in the frame over the twelfth-century mosque in Marrakech, Morocco. In both images a line divided into $n$ equal parts has been inserted and we can easily see how the timbers reflect the sequence described: G, 2G, G, 2G, and so on. The tiny discrepancies between the exact division of the line and the perceived position of the timbers are simply owing to the slight deformation that these structures have evidently undergone through the ages.

Timber width was therefore the standard unit of measurement for the execution of the entire work. On this matter, Enrique Nuere remarks:

At a time when units of measurement varied, it is clear that the use of a unit of measurement already present in the work to be executed must have

\footnotetext{
3 The language of the original text in old Spanish is highly cryptic and difficult to translate even into modern Spanish. In old Spanish: “.. desde un grueso hasta el otro la cantidad de dos gruesos del par, y esta cantidad es lo que los arquitectos de carpinteria dizen calle y cuerda.”.
} 


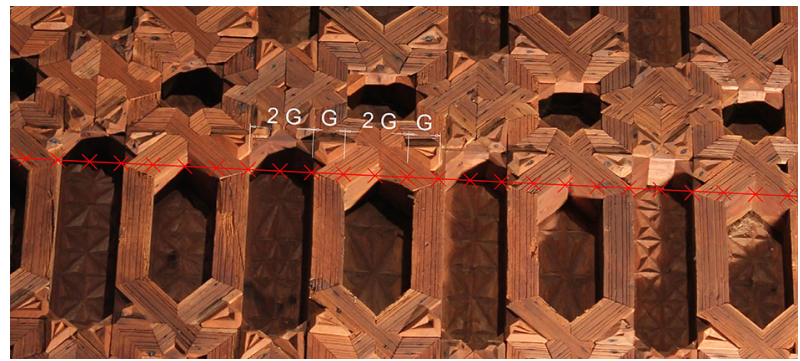

Fig. 9 Confirmation of sequencing in the position of structural elements in the 16th-century Church of San Francisco, Ayamonte (Spain). Photo and drawing by the author

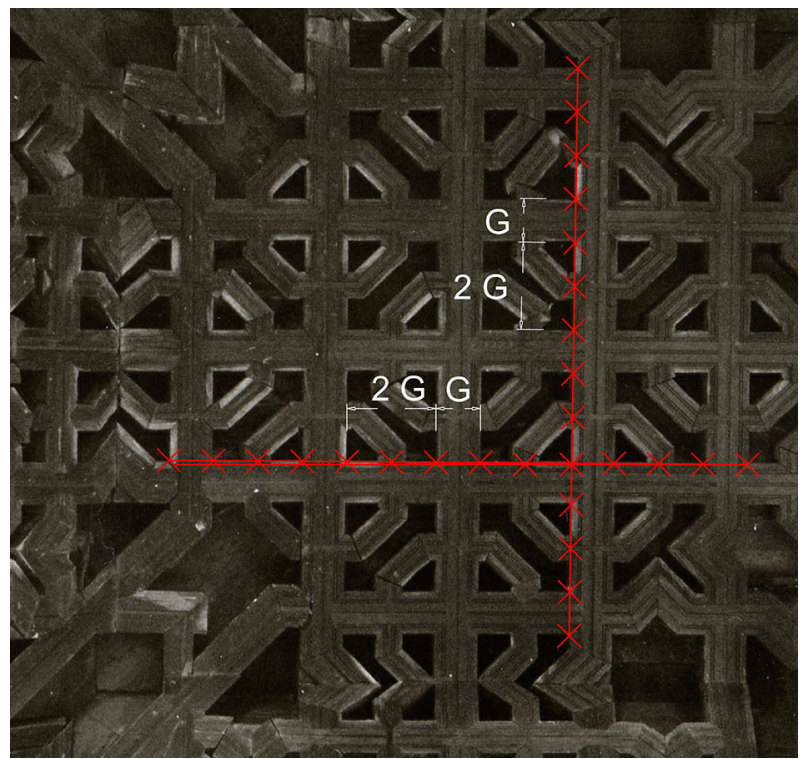

Fig. 10 Confirmation of sequencing in the position of structural elements in the 12th-century mosque in Marrakech (Morocco). Photo courtesy of Christian Ewert. Drawing by the author

proliferated to a greater extent than a method or system based on the application of a Castilian foot or Sevillian rod... (1985: 87).

However, the question remains of how the carpenters determined the dimension of this width. Three aspects converged simultaneously in this determination: the position of the collar beam, the interlace pattern that had to be inserted, and the width of the room to cover.

In the first instance, the canonical, most common position of the collar beam was at a third of the total height of the roof truss. This meant that, irrespective of the roof pitch, the plan view of the collar beam divided the width of the building into three equal parts. This position is described in the aforementioned treatises, as evidenced by the following excerpt from the manuscript of Rodrigo Álvarez: "The building is 
divided from one corner or angle of the wall plate to the opposite angle in three equal parts, and one of these partitions is what the collar beam must measure" (c.1670: 36v). ${ }^{4}$

An example of this position is shown in Fig. 11, taken in the Church of Nuestra Señora del Vado in Gibraleón, Huelva (Spain).

The first operation was therefore to divide the building width into three equal parts to determine the length of the collar beam. With regard to the second aspect, the customary existence of an interlace pattern on the horizontal plane (almizate ${ }^{5}$ in Spanish) where the collar beams were placed dictated a rectangular pattern arising from the convergence of the rafters from the side panels and the front panel of the roof frame. Before embarking on the design, it was necessary to decide which interlace pattern to insert. This could range from simple formations of interlacing eight-pointed stars to complex combinations of stars with a varying number of points. Each interlace pattern also required a certain number of elements to configure the design. Thus, having decided on the interlace design, a specific number $N$ of transversal elements had to be placed on the transversal section of the frame, along the collar beam (Fig. 12). As we shall see, these small transversal elements, known as noggings, (peinazo in Spanish), constitute a veritable compendium of roof frame geometry.

The aforementioned treatises include samples for these patterns (Fig. 13) and there are records of work contracts attaching the basic geometry of the interlace design to insert. Each design has its own exact number of transversal elements.

The next example (Fig. 14) shows a construction including eight transversal noggings $(N=8)$, while the bay between rafters equals $3 G(n=3)$.

The final aspect mentioned above is the building width. We have already seen that this width had to be divided into three equal parts, and we also know from the sample interlace pattern that the transversal elements between collar beams had to follow the sequence $G, n G, G, n G \ldots$; in other words, the axes are positioned at intervals of $G(n+1)$. Armed with this information, the carpenter could easily calculate the width at which he had to cut the timber: he simply had to divide a third of the room into $n+1$ times the number of transversal elements desired. Figure 15 shows that construction which may be expressed as:

$$
L / 3=N \times(n+1) \times G,
$$

and therefore,

$$
G=L /(3 \times N \times(n+1)),
$$

where $G=$ timber width; $L=$ building width; $N=$ number of transversal elements; $n=$ bay between rafters coefficient.

In practice, as we saw in Figs. 9 and 10, the most common bay between timbers was twice their width $(n=2)$, so the bay between element axes is $3 G$. To determine

\footnotetext{
${ }^{4}$ In old Spanish: "se partira el cuerpo o Ancho del edificio Desde la un ${ }^{a}$ esquina o angulo Del strivamento, asta el angulo opuesto, en tres partes yguales, Y formar esta particion en una Regla. Y sera una Destas destas Particiones la cantidad Del nudillo.".

5 From the Arabic, meaning "the centre" or "central area".
} 


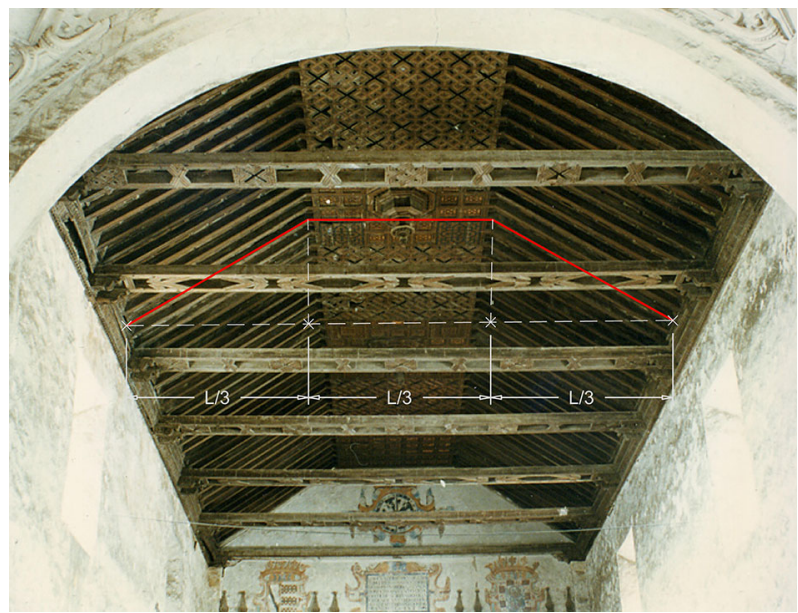

Fig. 11 Confirmation of the division of the building width into three equal parts. 17th-century Church of Nuestra Señora del Vado, Gibraleón, Huelva (Spain). Photo and drawing by the author

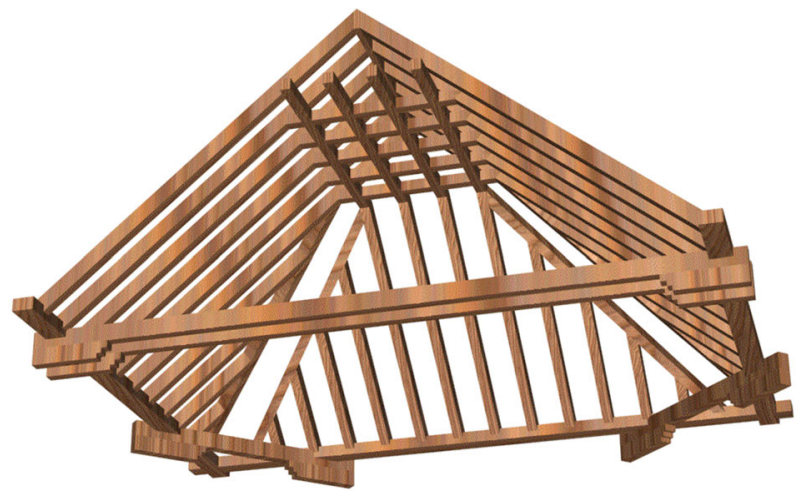

Fig. 12 Drawing of typical Mudéjar tmber roof frame showing the formation of a rectangular pattern on the horizontal plane of the roof. Drawing by the author

$G$, it was simply a case of dividing the width into nine times the number of transversal elements, as indicated in the text by López de Arenas:

Placing the collar beam at a third and the bay between timbers being twice the width and if there are three noggings, the width of the timber will be one twenty-seventh of the width of the house and the collar beam will have nine times the width and the house 27... (López De Arenas 1619: 5v). ${ }^{6}$

\footnotetext{
${ }^{6}$ In old Spanish: sirviendo el nudillo al tercio y a calle y cuerda llevare tres manguetas el grueso de las maderas será uno de veinte y siete gruesos del testero de la casa y el nudillo tendrá 9 gruesos y la casa $27 \ldots$
} 


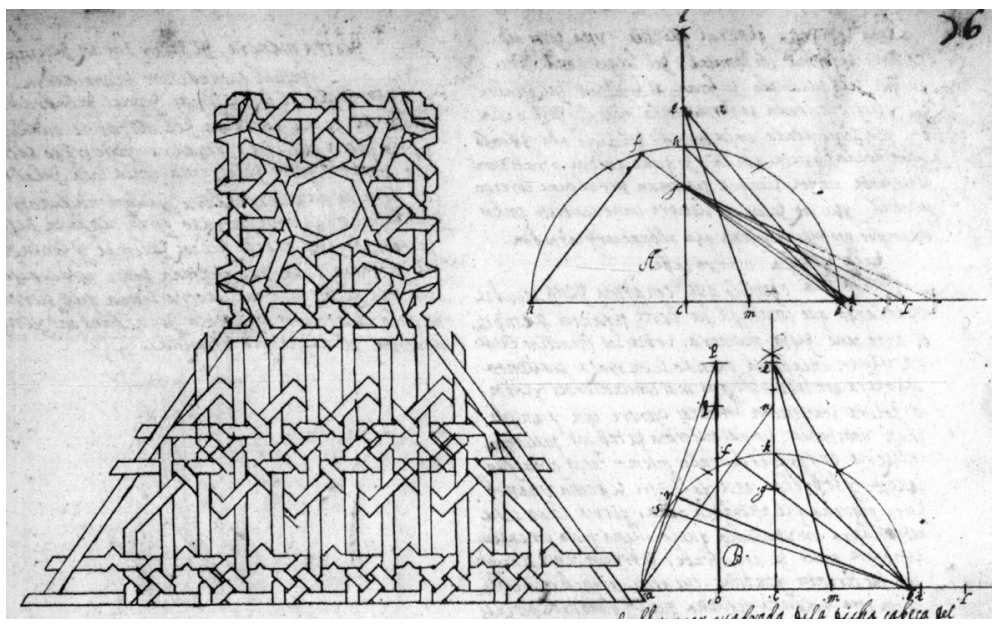

Fig. 13 Sample interlace pattern. Image: (San Miguel c.1652: 76)

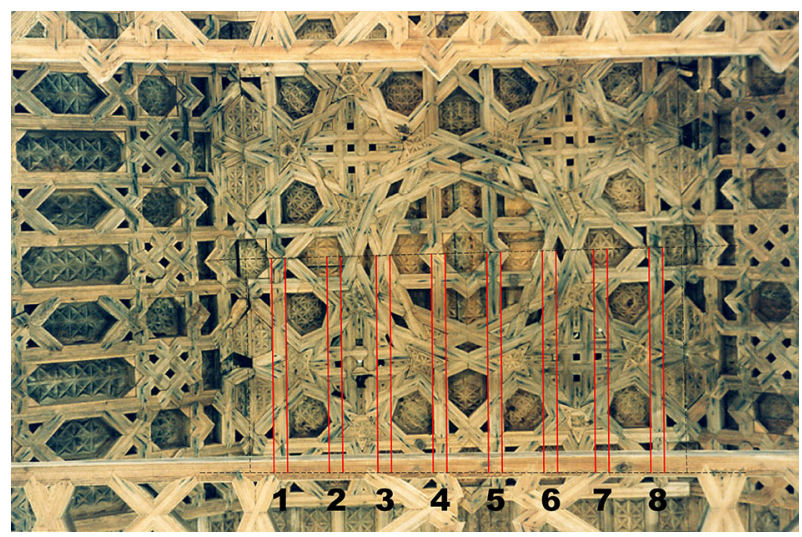

Fig. 14 Horizontal plane of collar beams showing the regular design, the number of transversal elements and the bay between them. Photo and drawing by the author

\section{Rafter section}

Having defined the timber width, the depth of the rafter was calculated, according to the treatises, using the $45^{\circ}$ set square as described in the following statement:

The depth of the common rafters and jack rafters is identical and obtained by placing the base line of the $45^{\circ}$ set square on the rafter width, and that is its depth... (López De Arenas 1619: 6). ${ }^{7}$

\footnotetext{
7 In old Spanish: Alto de las alfardas y pendolas es todo uno sale su alto echando cola del quadrado por el grueso del par y aquel es su alto....
} 


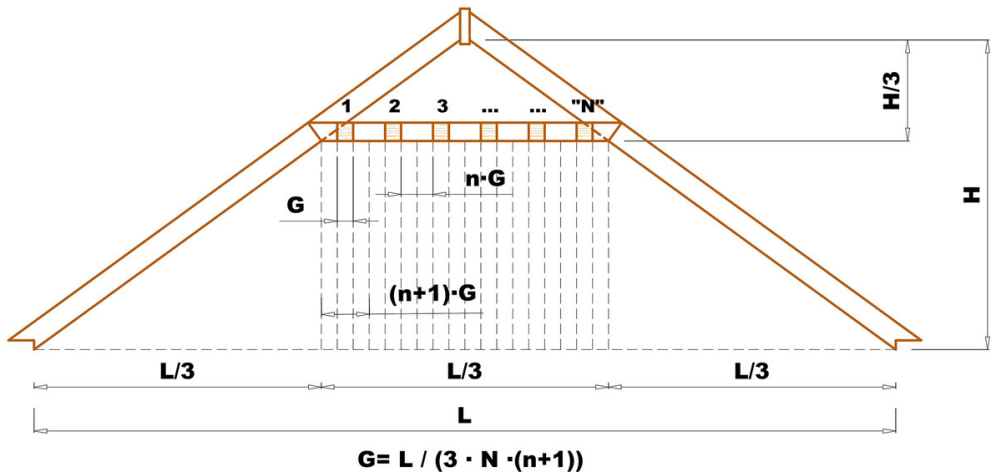

Fig. 15 Determination of timber width. Drawing by the author

In short, the depth of the rafter is the length of the straight line which with an angle of $45^{\circ}$ may be inscribed in a hypothetical rectangle whose shortest side is the width $G$ defined above. Its graphical representation is the simple construction shown in Fig. 16.

This may be expressed simply as:

$$
h r=G \times \sqrt{2}
$$

where $G$ is the width of the rafter, equal to the width of the collar beam.

\section{Roof pitch}

Having defined the cross section of the timber pieces, the carpenter then had to determine the roof pitch. This pitch could not be arbitrary but had to correspond to an angle he knew how to draw. At the same time it had to ensure correct drainage and avoid tile slippage. For this he could use the angles obtained by dividing the semi-circumference into four parts $\left(45^{\circ}\right)$ or five parts $\left(36^{\circ}\right)$, or even-rare but possible-four and a half parts $\left(40^{\circ}\right)$. Pitches at a greater angle might cause coverage issues due to tile slippage, while smaller angles might allow water to seep between the tiles. The most common angle, as confirmed in the vast majority of

Fig. 16 Determination of the rafter section. Drawing by the author

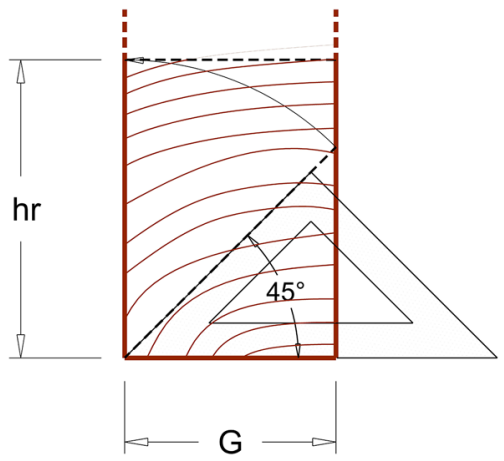


buildings that exist today, was the set square of $5\left(36^{\circ}\right)$. Several paragraphs in the treatise of López de Arenas (1619) even refer to the set square of 5 as the "truss square".

\section{Collar beam section}

Now that the pitch of the roof had been chosen, the depth of the collar beam could be determined, as indicated in the following text:

The depth of the collar beam is obtained by placing the right angle of the $45^{\circ}$ set square on the lateral face of the rafter and drawing two lines with the angle of the truss square. The space between one and the other is the depth of the collar beam and that depth is infallible (López De Arenas 1619: 4). ${ }^{8}$

In light of the indication above, the depth of the collar beam is the distance between two "truss squares" placed along the perpendicular line of the rafter. That size is derived from formal appearance rather than from their structural behaviour. The geometric construction is shown in Fig. 17. The mathematical expression could not be simpler:

$$
h_{n}=h_{r} \times \cos \alpha
$$

where $h_{n}=$ depth of the collar beam; $\alpha=$ angle between the long side and base of the set square, or roof pitch; $h_{r}=$ rafter depth already determined.

Consequently, the collar beam depth can also be expressed according to its own width:

$$
h n=G \times \sqrt{2} \times \cos \propto .
$$

\section{Other historical examples of the use of timber width as a unit of measurement}

I have not found any other examples in Europe where the width of a building element regulates an entire and highly complex construction. The only reference I might make is to construction with bricks, where the entire or partial dimensions of a brick define the sections of simple elements like columns or pillars but are not used to calculate bays or other elements.

Interesting to note in this respect, although it is not related to building elements, is the existence of an Arabic calligraphy system invented by Ibn al-Bawwab (late tenth century), who developed a system of proportional measurement whereby each letter could be measured by its height and width in dots, with each dot the same width as the nib of the reed pen (see http://calligraphyqalam.com/people/ibn-albawwab.html).

Surprisingly, China offers an example in the ancient construction of timber structures where the procedures followed were also based on the use of timber width as a regulating element. I refer to the Chinese building tradition that started in the

\footnotetext{
${ }^{8}$ In old Spanish: El alto del nudillo es echando cabesa de quadrado en la tabla del alfarda y asesles dos colas de armadura y lo que ai de la una a la otra es el alto del nudillo y es infalible este su alto.
} 


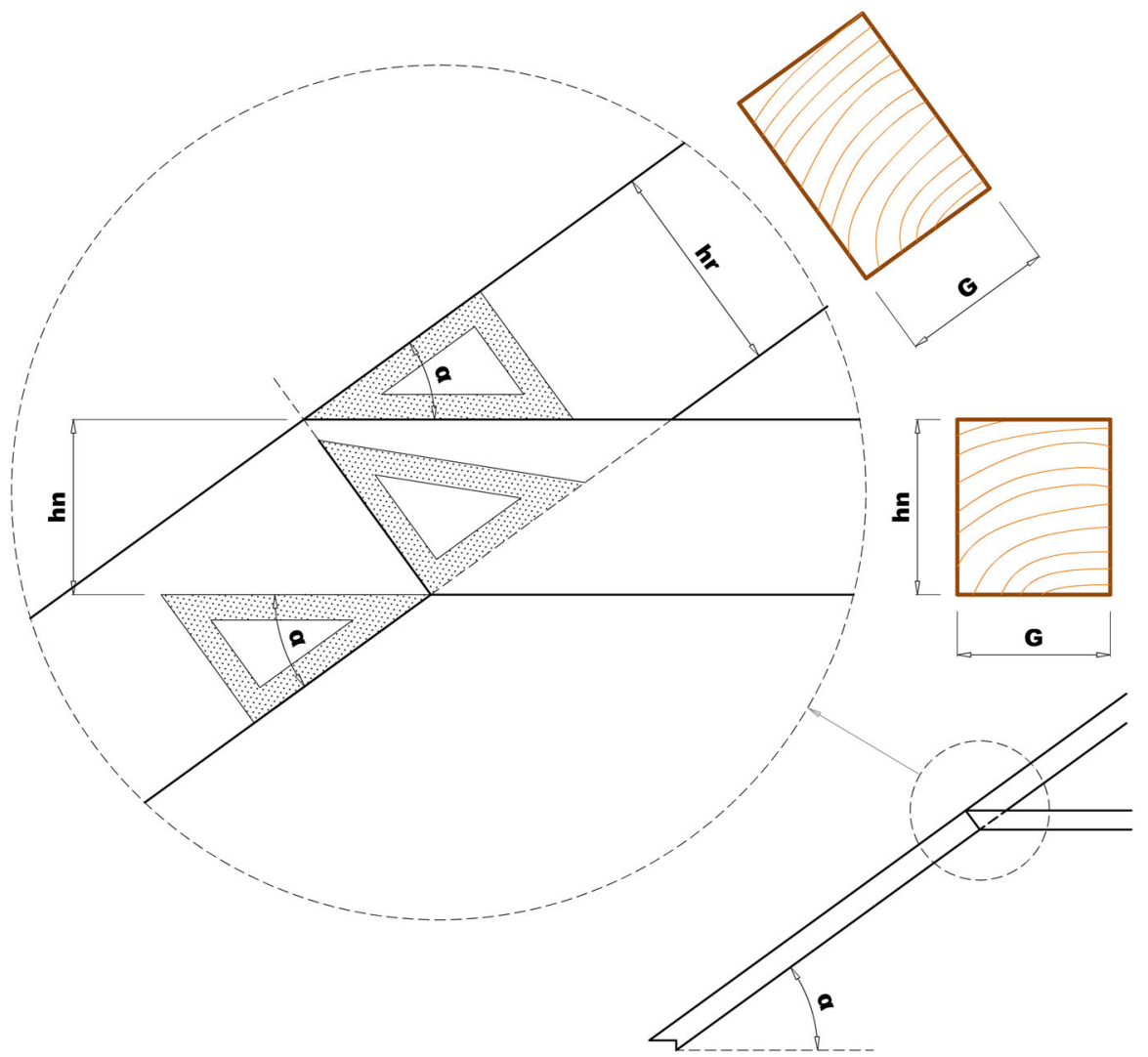

Fig. 17 Determination of the depth of the collar beam according to the width and the truss square. Drawing by the author

twelfth century, at a time when cultural exchanges between the Western and Eastern worlds were already taking place. The building skills used in China at this time are described in the Yingzao Fashi, or "Treatise on Architectural Methods or State Building Standards". It was written in 1103 by Li Jie, an architect in the Chinese court during the Song Dynasty. The text was rediscovered in 1919 and printed as a facsimile in 1920.

The first news and translation of the text in the West were probably owing to $\mathrm{P}$. Demevielle in 1925. According to Demiéville's description, one of the many topics covered by the text is the classification of buildings into eight categories, with dimensions proportionate to the basic building elements: "The tenth part of the width is adopted as the module and is used to determine the proportions of all 'major timber works'. The name of this unit is 'fen'..." (Demiéville 1925: 246). The most recent contributions in this respect are the various studies undertaken by Quinghua Guo (1998), Nujaba Kabir (2012), and especially Andrew Li (2011, 2015), who in that particular study and others uses the Yingzao Fashi to explain and discuss grammatical approaches to design analysis and as a basis for parametric design. 


\section{Inversion Geometry}

Adherence to these rules is what allows us today to recreate a historical roof frame based on a tiny fragment of its structure. This fragment is the nogging, the piece placed between two adjacent collar beams or rafters. In most cases it is a timber parallelepiped no more than $20 \mathrm{~cm}$ long, a distinctly modest and secondary element in a frame (Fig. 18).

We shall see how this tiny fragment contains a veritable compendium of the geometry used in the construction to which it belongs because it will enable us to work out the exact values of the rafter and collar beam cross sections, the bay between the rafters and their pitch. We can even work out the length of each of these elements.

To demonstrate this, I will use the following example. Let us suppose that in a historical building we have found a piece of timber whose dimensions in centimetres are 9.2 (width) $\times 10.5$ (depth) $\times 18.5$ (length), and at each end the piece displays the characteristic pegs that confirm that it is indeed a nogging (Fig. 19). Enrique Nuere was kind enough to build the hypothetical nogging for this purpose.

\section{Calculating the Module, Element Sections and Roof Pitch}

Each nogging forms an integral part of the interlace pattern, which means that all the elements - the nogging itself, rafters and collar beams-have to be the same width. Otherwise, it would be impossible to create a regular interlace design. Indeed, even in the case of modest frames with no interlace patterns, the noggings, ties and any other secondary elements usually have the same width as the timbers in the main structure.

The width of all the elements will therefore be $9.2 \mathrm{~cm}$, like that of our nogging. The bay between sets of rafters and collar beams will obviously be the length of our nogging. As we can see, in this case the length-18.5 cm-is approximately twice the width. It is clear, therefore, that this element forms part of a roof frame built according to the strict criterion of a calle y cuerda: in other words the spacing of the timbers at regular intervals was based on the actual width of the timbers used, which more often than not was twice their width.

This information tells us that $G=9.2 \mathrm{~cm}$, and $n=2$.

We can now calculate the depth of the rafter by using the previous equations.

$$
h_{r}=G \times \sqrt{2} ; \quad h_{r}=9.2 \times \sqrt{2}=13.01 \mathrm{~cm} .
$$

The depth of our nogging is $10.5 \mathrm{~cm}$, and it is therefore a piece that would have been placed between two collar beams. Furthermore, that dimension would be the depth of all the collar beams in the structure since the nogging usually has the same depth as the elements it links.

The carpenters' bright idea of relating the depth of the collar beam to the truss square is what will enable us to work out the roof pitch since we know the cross section of the collar beam and there is only one possible relationship. In this case: 


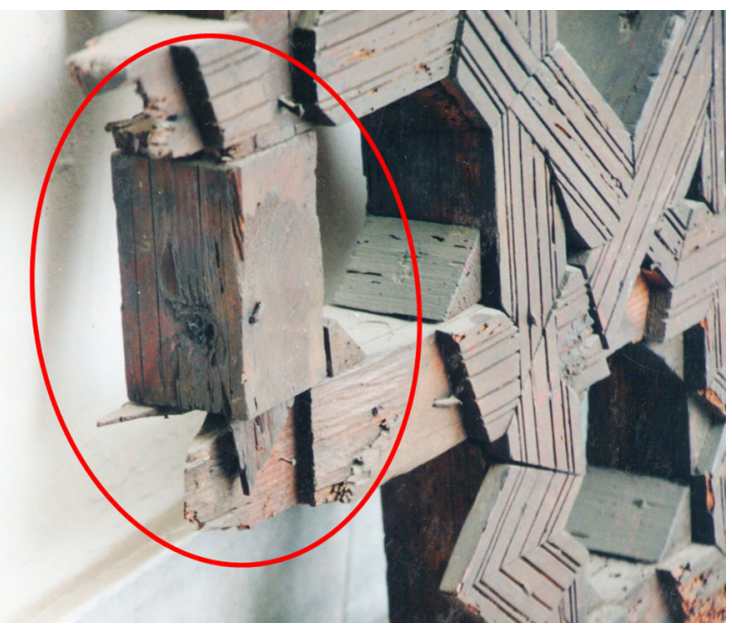

Fig. 18 Example of a nogging in a frame with interlace patterns. Photo by the author

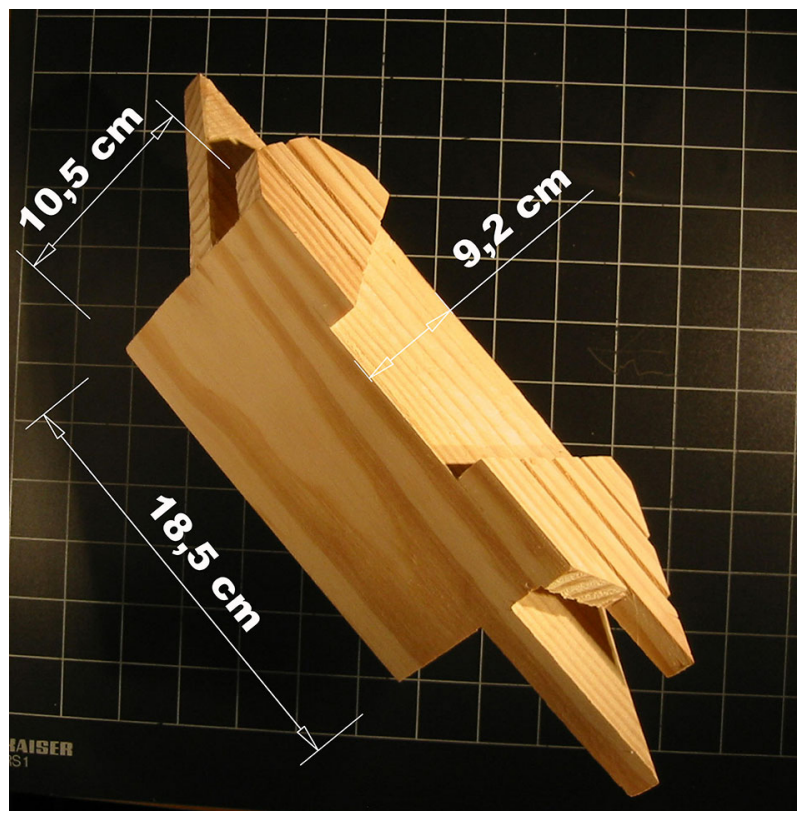

Fig. 19 The nogging built as an example by Enrique Nuere. Photo courtesy of Enrique Nuere

$$
h_{n}=G \times \sqrt{2} \times \cos \alpha \rightarrow \alpha=a \cos \left(\frac{h_{n}}{G \times \sqrt{2}}\right) \rightarrow \alpha=a \cos \left(\frac{10.5}{9.2 \times \sqrt{2}}\right)=36.19^{\circ}
$$

In fact, the frame would have been built with one of the set squares used by the carpenters, which respond to exact divisions of the semi-circumference. In this case, 
it would be the most common one, the set square of 5 , whose smallest angle is $36^{\circ}$, and that would be the roof pitch.

\section{Interlace Pattern}

If we now look at the upper face of the nogging, we see two sloping lines flanking a groove in the timber (Fig. 20). The angle of this inclination is $67.5^{\circ}$, and we can confirm that it can only correspond to the cut made to create an eight-pointed star. Any other star pattern would have required very different angles. In fact, the measurement of this angle does not even need to be so exact because the angles of stars vary enormously depending on the number of points. For example, a sevenpointed star would require an angle of $77^{\circ}$, whereas in a nine-pointed star it would be $60^{\circ}$.

We can therefore deduce that the frame to which the fragment belongs included an eight-pointed star design. This single piece of information does not provide any more details about the pattern, which might have consisted in a regular chain of stars or could have constituted interlacing polygons of varying shapes. However, if we had another nogging we could almost certainly work out the exact formation by a deductive method.

\section{Hypothesis about Length of the Collar Beam and the Frame Span}

The above deductions about sections of elements, the bays between them, roof pitch and even the interlace eight-pointed star pattern are indisputable.

We can go even further and determine the length of the collar beam and the width of the building where our nogging was found. This involves a greater number of variable factors, but it is still possible to establish certain hypotheses which, as we shall see, narrow down the possible solutions.

Two factors impact these deductions. First, the existence of the interlacing eightpointed star pattern means that the total number of noggings must be an even

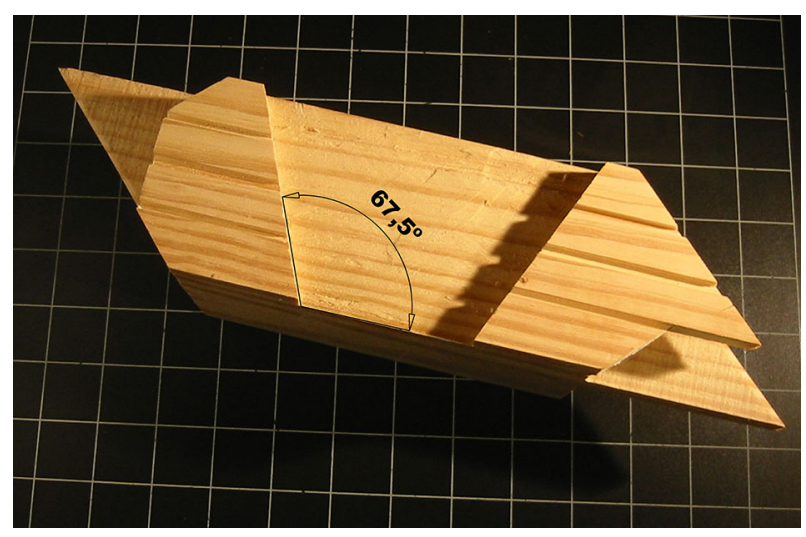

Fig. 20 Traces of interlace pattern in the nogging. Photo courtesy of Enrique Nuere 
Table 1 Possible widths with different numbers of noggings

\begin{tabular}{llllll}
\hline Number of noggings $(\mathrm{N})$ & $\mathbf{4}$ & 6 & 8 & 10 & $\mathbf{1 2}$ \\
Span to cover $(\mathrm{cm})$ & $\mathbf{3 3 1}$ & 497 & 662 & 828 & $\mathbf{9 9 3}$ \\
\hline
\end{tabular}

number: odd numbers are possible in theory but in such a case the existence of a structural element in the central axis of the almizate would mean that a star could not be positioned on the axis of symmetry, which is extremely rare. Meanwhile, there is another circumstance of vital importance. I indicated earlier that in Mudéjar timberwork the interlace design also formed part of the roof structure. Accordingly, the cross section of the timbers used must be able to withstand the roof (dead), wind and snow (live) loads. Based on their experience, carpenters were able to judge the suitability of a particular cross section for the dimensions of the space to span. This circumstance-the structural capacity of the elements-narrows down the possibilities.

By inverting the previous equation, we can calculate the possible widths of the building in which the nogging in our example formed part of the structure:

$$
L=3 \times N \times G \times(n+1) .
$$

In our case, as we worked out earlier, $G=9.2 \mathrm{~cm} ; n=2$.

Therefore, assuming $N$ to be even, and limiting the value of $L$ to the maximum and minimum dimensions of this typology, we can define the possible widths of the building $L$ as shown in Table 1 .

Dimensions corresponding to four or fewer noggings and twelve or more noggings (bold in the table) can be ruled out, either due to the resulting narrowness of the building or because the section of the timbers would not be capable of withstanding the acting loads, and therefore the width of the space covered by this would be 497, 662 or $828 \mathrm{~cm}$ (Fig. 21).

As we can see, one tiny fragment would enable us to work out practically all the dimensions of the structure of which it formed part. Consequently, we may consider the nogging to constitute a veritable compendium of geometric relationships as well as a generative element in the structure of interlace patterns in Mudéjar roof frames.

\section{Discussion}

This article provides a brief description of a very small part of medieval knowledge about the geometry used to build complex roof frames in constructions spanning a wide temporal and geographic scope. This knowledge has come down to us from texts published at a later date (seventeenth century). Armed with this knowledge, carpenters were not only able to build structural elements but, astonishingly, could also include in them complex interlace patterns composed of stars with different numbers of points.

The procedures followed to build roof structures were based on determining the most suitable timber width for the work in question, and having defined that size it 

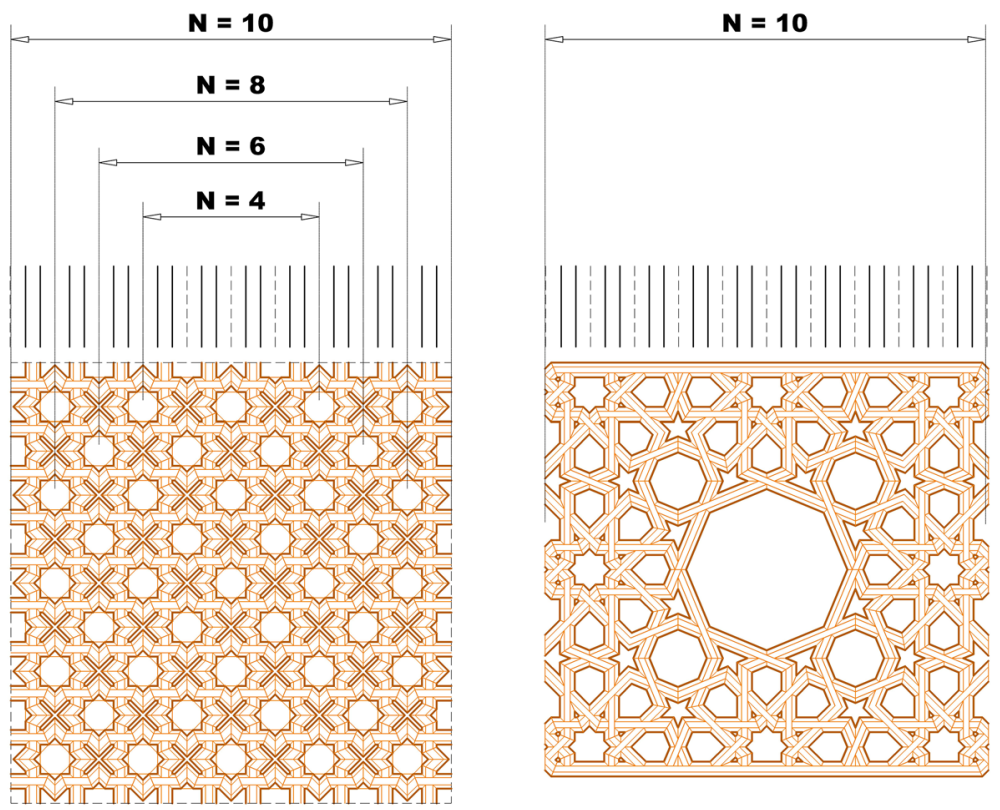

Fig. 21 Possible interlace patterns related to this model. Drawing by the author

was adopted as the unit of measurement for the entire construction. This module and the use of a specific number of set squares permitted the construction of a wide range of complex structures, including domes and vaults, faceted and curved, into which interlace patterns with different types of stars were inserted, forming part of the actual structure rather than simply serving as an overlaid decorative feature. This use of a practical unit of measurement can be regarded as intrinsic to the construction and contrasts with the more common use of extrinsic units of measurements, such as the local standard unit, as well as with other relationships associated with various well-known systems of proportional relationships.

One original contribution made here lies in the confirmation in ancient buildings that exist today of the adherence to and persistent use of timber width as a unit of measurement and the entire modulation of the structure based on a system in which the bay between element axes was usually three times this width.

After describing the main rules used, this article has attempted to demonstrate the capacity of those rules for analysing and recreating these constructions from tiny fragments. As our example we have used a small, seemingly secondary element-a nogging - that has enabled us to work out the exact dimensions of the rafters and collar beams, the bay between rafters, and the interlace pattern that was inserted. We can even estimate the dimensions of the building that supported the roof. Consequently, we may conclude that this tiny fragment constitutes a compendium of the geometry of the frame to which it belongs.

Acknowledgements I thank Dr. E. Nuere for his masterful teaching an also for carving the nogging used as example in this article. 


\section{References}

Álvarez, Rodrigo. c.1670. Breve compendio de la carpintería y tratado de lo blanco, con algunas cosas tocantes a la Iometría y puntas del compás. Salamanca. Ms. No. 557, library at Fundación Lázaro Galdeano, Madrid. Available in http://www.bibliotecavirtualmadrid.org/bvmadrid_publicacion/es/ consulta/registro.cmd?id=3503.

Bodner, B. Lynn. 2012. From Sultaniyeh to Tashkent Scrolls: Euclidean Constructions of Two Nine- and Twelve-Pointed Interlocking Star Polygon Designs. In Nexus Network Journal 14 (2):307-332. doi:10.1007/s00004-012-0111-y.

Candelas-Gutiérrez, Angel. 2000. Bóvedas de madera: ¿Se pueden construir según describen los tratados? In Actas del Tercer Congreso Nacional de Historia de la construcción, vol. I, 193-204. Sevilla.

Candelas-Gutiérrez, Angel. 2011. La carpintería de armar medieval. In La técnica de la arquitectura medieval. Ed. Amparo Graciani, 271-297. Sevilla: Universidad de Sevilla.

Corcuff, Marie-Pascale. 2012. Modularity and Proportions in Architecture and their Relevance to a Generative Approach to Architectural Design. Nexus Network Journal 14(1):53-73. doi:10.1007/ s00004-011-0097-x.

Demiéville, Paul Henri. 1925. Un traité d'architecture chinois: le Ying-Tsao-fa-che de Li Ming Tchong des Song. In Bulletin de l'Ecole française d'Extrême Orient, XXV: 213-264.

Deneux, H[enri]. 1927. Évolution des charpentes du XI au XVIII siècle. L'architecte (Jul-Nov 1927): 49-53, 57-60, 65-68, 73-75, 81-89.

Fernie, Eric. 1978. Historical Metrology and Architectural History. Art History 1(4): 385-399.

García Nistal, Joaquín. 2011. Mudéjar coffered ceilings?. About some terminological and investigative questions in the spanish carpentry studies. In Anales de Historia del Arte. Volumen extraordinario: 211-223. doi: 10.5209/rev_ANHA.2011.37458

Ghyka, Matila C. 1931. Le Nombre d'or. Paris: NRF.

Guo, Qinghua. 1998. Yingzao Fashi: Twelfth-Century Chinese Building Manual. Architectural History 41: 1-13. doi:10.2307/1568644

Hernández Jiménez, Félix. 1961. El codo en la historiografía árabe de la Mezquita Mayor de Córdoba. Contribución al estudio del monumento. Al-Mulk 2: 5-52.

Hewett, Cecil A. 1980. English Historic Carpentry. London: Phillimore.

Jousse, Mathurin. 1627. Le théâtre de l'art de charpentier. La Flèche: Georges Griveau.

Kabir, Nujaba Binte. 2012. Chinese wood frame buildings and the changing dimensions of their structural components in different time periods. Journal of Design and Built Environment 10(1).

Klein, H.A. 1974. The World of Measurements: Masterpieces, Mysteries and Muddles of Metrology. New York: Simon and Schuster.

Kula, Witold. 1980. Las medidas y los hombres. Madrid: Siglo XXI.

Li, Andrew I-kang 2011. Computing Style. Nexus Network Journal 13(1): 183-193 doi:10.1007/s00004011-0053-9

Li, Andrew I-kang 2015. Algorithmic Architecture in Twelfth-Century China: The Yingzao Fashi In Architecture and Mathematics from Antiquity to the Future. 389-397. K. Williams and M.J. Ostwald (eds.) Springer International Publishing Switzerland doi:10.1007/978-3-319-00137-1_27.

López De Arenas, Diego. 1619. Primera y segunda parte de las reglas de carpintería, fecho por Diego López de Arenas en este año de MDCXVIII. Facsimile edition of the first manuscript with introduction and technical glossary by Manuel Gómez Moreno. Madrid: Instituto de Valencia de Don Juan, 1966

López de Arenas, Diego. 1633. Breve Compendio de la Carpintería de lo Blanco y Tratado de Alarifes, y otras cosas tocantes a la ieometria y puntas del compas. Facsimile of the first edition in Sevilla by Luis Estupiñan with introduction by Enrique Nuere. Ed. Albatros. Valencia, 1982

Michell, John. 1981. Ancient Metrology. Bristol: Pentacle Books.

Nuere Matauco, Enrique. 1985. La carpintería de lo blanco. Lectura dibujada del primer manuscrito de López de Arenas. Madrid: Ministerio de Cultura.

Nuere Matauco, Enrique. 2000. La carpintería de armar española. Madrid: Munilla-Lería.

Oikonomou, Aineias. 2011. The Use of the Module, Metric Models and Triangular Tracing in the Traditional Architecture of Northern Greece. Nexus Network Journal 13(3): 763-792. doi:10.1007/ s00004-011-0090-4.

Roldán[-Medina], Francisco. 2012. Method of modulation and sizing of historic architecture. In Nexus Network Journal 14(3): 539-553. doi:10.1007/s00004-012-0125-5. 
Roldán-Medina, F. J. 2015. Análisis antropométrico de la mezquita-catedral de Córdoba. In Informes de la Construcción, 67(539): e093. doi:10.3989/ic.14.024.

Ruiz de la Rosa, José Antonio. 1987. Traza y simetría de la Arquitectura: En la Antigüedad y el Medievo. Sevilla: Universidad de Sevilla.

San Miguel, Fray Andrés de. c.1652. Benson Latin American Collection, General Libraries, The University of Texas at Austin, Ms. 31775792. Facsimile rpt. in La carpintería de lazo. Lectura dibujada del manuscrito de Fray Andrés de San Miguel. Enrique Nuere, ed. COAM. Malaga, 1990.

Shtrum, Batyah, Melanie Brussat, Miguel Garcia, Timothy Hayes and Stephanie Massaux. 2011. The Metropolitan Museum of Art's 'Spanish Ceiling' Project: Interpretation and Conservation. In Journal of Architectural Conservation 16(3): 29-50. doi:10.1080/13556207.2010.10785074.

Vandevyvere, Han. 2001. Gothic Town Halls in and around Flanders, 1350-1550: A Geometrical Analysis. In Nexus Network Journal 3(2): 59-84. doi:10.1007/s00004-001-0023-8.

Wittkower, Rudolf. 1960. The Changing Concept of Proportion. Daedalus 89(1) (Winter 1960): 199-215.

Wulff Barreiro, Federico. 2010. Origen y evolución de la carpintería de armar hispano-musulmana: de los antecedentes romanos, bizantinos y sirios hasta la carpintería almohade. Ph.D. thesis, Universidad Politécnica de Madrid.

Angel Candelas-Gutierrez obtained his degree in Architecture from the Seville University School of Architecture in 1982, and he completed his PhD on Spanish medieval timberwork in 1999. He has carried out several restoration projects in historical buildings with Mudéjar timber frames, combining his knowledge of historical constructive systems with the implementation of modern restoration methods. He is currently a Tenured Lecturer at the University of Seville, where his teaching is mainly related to lightweight building systems. His research interests are construction history, restoration methods, and medieval and Islamic architecture 